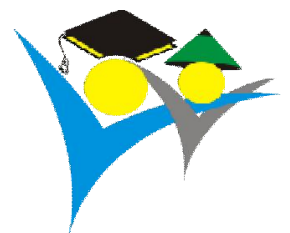

Jurnal SIAR ILMUWAN TANI

online http://siarilmuwantani.unram.ac.id

Vol. 2 No. 1, pp: 1-9

|p-issn 2722-5488|e-issn 2722-5496|

J uni 2021

DOI: https://doi.org/10.29303/jsit.v2i1.40

\title{
Diseminasi Teknologi Budidaya Tanaman Wortel Ramah Lingkungan Di Dataran Rendah
}

\author{
Aluh Nikmatullah ${ }^{1}$, Karwati Zawani ${ }^{1}$, Nurrachman ${ }^{1}$, Rukmini Kusmarwiyah ${ }^{1}$, Herman Suheri ${ }^{1}$, \\ Khaerul Muslim ${ }^{1}$
}

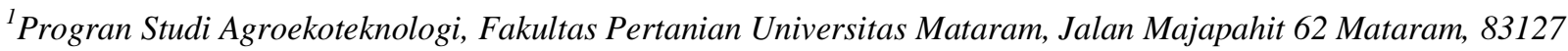

\section{Article history}

Received: 9 Juni 2021

Revised: 10 Juni 2021

Accepted: 21 Juni 2021

*Corresponding Author: Aluh

Nikmatullah, Fakultas

Pertanian Universitas Mataram,

Mataram, Indonesia

Email:

aluh_nikmatullah@unram.ac.id
Abstract: The increasing demand for a good quality of carrot tubers has yet been achieved, partly due to limitation in cultivation area. Extension of cultivation to low land has been attempted and suitable cultivation technology with yields 17.5 - 25 ton/ha has been developed. However, cultivation of carrot in lowlands is very limited as farmers assume that carrots cannot be cultivated in the lowlands. To promote this, a community service (PKM) aimed to disseminate environmentally-friendly carrot cultivation technology in the lowlands has been undertaken in Bagik Polak Village, Labuapi District, West Lombok Regency from June to October 2020. The PKM was carried out in collaboration with the Gapoktan Bersatu and UPTD Agriculture of Labuapi District, through demonstration plots and extension. The activity began with socialization by discussion with the officials of Labuapi UPTD Agriculture and management of the Bersatu Gapoktan, followed by demplot for carrot cultivation at an altitude of $\pm 41 \mathrm{~m}$ above sea level. At harvest time, the demplot results were exposed to the community via extension at the house of the Gapoktan leader. By directly observing the demplot results, participants were motivated to cultivate environmentally-friendly carrots, and stated that they will undertake trials in theirs fields. The Labuapi UPTD will set a demplot in the UPTD yard and promote carrot plants in the program for yard optimality. In addition, the farmers agreed that this activity has bring a new inspiration to diversify vegetable crops with a higher economic crops

Keywords: Carrot, ecofriendly, lowland, dissemination, Lombok

Abstrak: Peningkatan permintaan terhadap umbi wortel bermutu belum bisa dipenuhi antara lain karena keterbatasan areal budidaya, sehingga dilakukan pengembangan budidaya wortel di dataran rendah, baik secara konvensional maupun dengan pendekatan ramah lingkungan, dengan hasil 17,5 -22,5 Ton/Ha. Meskipun demikian, budidaya wortel di dataran rendah belum dilakukan oleh masyarakat anggapan bahwa wortel tidak bisa dibudidayakan di dataran rendah, sehingga telah dilakukan Pengabdian Kepada Masyarakat (PKM) dengan tujuan mendiseminasikan teknologi budidaya tanaman wortel ramah lingkungan di dataran rendah. PKM dilakukan di Desa Bagik Polak, Kecamatan Labuapi, Kabupaten Lombok Barat dengan mitra Gapoktan bersatu dan UPTD Pertanian, Kecamatan Labuapi, mulai bulan Juni sampai sampai Oktober 2020 melalui penyuluhan dan demplot. Kegiatan diawali dengan sosialisasi melalui kunjungan tim ke UPTD Pertanian Labuapi dan diskusi terbatas dengan pengurus Gapoktan Bersatu dilanjutkan dengan demplot budidaya di lahan milik Gapoktan Bersatu (pada ketinggian $\pm 41 \mathrm{~m} \mathrm{dpl}$ ). Pada saat panen, dilakukan ekspose hasil demplot dengan penyuluhan di rumah ketua Gapoktan Bersatu pada tanggal 8 Oktober 2020. Dengan melihat langsung hasil demplot, peserta termotivasi untuk melakukan budidaya tanaman wortel ramah lingkungan secara mandiri dengan mencoba pada lahan sawah, pekarangan mereka dan pada halaman UPTD Pertanian Desa Labuapi. UPTD Pertanian akan membuat demplot di halaman kantor UPTD Pertanian Desa Labuapi dan akan membuat tanaman wortel sebagai salah satu tanaman dalam program pembinaan pemanfaatan pekarangan di wilayah kerjanya. Selain itu, budidaya tanaman wortel merupakan inspirasi baru bagi petani sayuran dalam melakukan diversifikasi produk sayuran yang memiliki nilai ekonomi yang lebih tinggi.

Kata kunci: Wortel, ramah_lingkungan, dataran-rendah, diseminasi, Lombok 
J urnal SIAR ILMUWANTANI Vol. 2 No. 1, J uni 2021 Nikmatullah, Zawani, Nurrachman, Kusmarwiyah, Suheri, Muslim

\section{PENDAHULUAN}

Wortel (Daucus carota L.) merupakan tanaman sayuran yang diambil umbinya, dan digunakan sebagai salah satu sayuran utama yang dimakan sebagai sayuran segar maupun ditambahkan pada berbagai jenis masakan. Umbi wortel berwarna oranye terang, memiliki rasa gurih, renyah dan sedikit manis, dan kaya nutrisi terutama provitamin A. Umbi wortel juga dilaporkan mengandung berbagai mineral dan vitamin yang sangat dibutuhkan oleh tubuh manusia (Anonim, 2006; Berlian dan Rahayu, 1995) serta kaya antioksidant (Que et al., 2019). Di Indonesia, wortel dianjurkan sebagai bahan pangan potensial untuk mengentaskan masalah penyakit kurang vitamin A, karena kandungan karoten (pro vitamin A) pada wortel yang dapat mencegah penyakit rabun senja (buta ayam) dan masalah kurang gizi. Beta karoten di dalam tubuh akan diubah menjadi vitamin A, zat gizi yang sangat penting untuk fungsi retina (Khomsan, 2007).

Permintaan terhadap wortel diperkirakan akan terus meningkat seiring dengan peningkatan jumlah penduduk, peningkatan kesadaran masyarakat terhadap gizi, peningkatan pendapatan serta berkembangnya Indonesia termasuk Nusa Tenggara Barat sebagai daerah tujuan wisata. Selain untuk kebutuhan pasar tradisional, terdapat peningkatan permintaan untuk pemenuhan pasar modern, hotel dan restauran yang menuntut ketersediaan wortel bermutu yaitu wortel dengan ukuran umbi seragam, bentuk umbi sempurna, warna umbi cerah serta aman untuk dikonsumsi segar sebagai salad maupun jus buah. Sementara itu, produksi wortel di Indonesia dalam 5 tahun terakhir cenderung tetap, dari 522.529 Ton pada tahun 2015 menjadi 537.341 pada Tahun 2017 (BPS, 2020). Oleh karena itu, perlu upaya peningkatan produksi wortel baik melalui ektensifikasi, pengembangan teknologi produksi ramah lingkungan maupun perluasan areal budidaya. Daerah yang sesuai untuk budidaya tanaman wortel di Indonesia adalah daerah dataran tinggi (Mulyahati, 2005). Perluasan areal budidaya di dataran tinggi dihadapkan pada keterbatasan areal penanaman, dan areal tersebut semakin terbatas dengan adanya alih fungsi lahan pertanian menjadi fungsi lainnya. Oleh karena itu, perlu dilakukan perluasan areal penanaman ke dataran medium dan dataran rendah, kawasan dengan ketersediaan lahan pertanian yang lebih luas.

Tanaman wortel berasal dari daerah subtropis dan di negara tropis ditanam di dataran tinggi. Kendala utama pengembangan tanaman wortel di dataran rendah adalah suhu yang relatif lebih tinggi sehingga pertumbuhan dan hasilnya rendah (Firmansyah dkk, 2016). Menurut Nunez et al.(2008), suhu optimal untuk pembentukan umbi wortel adalah $18-28{ }^{\circ} \mathrm{C}$ dengan suhu di atas $30^{\circ} \mathrm{C}$ menyebabkan mutu umbi menurun. Selain faktor lingkungan, keberhasilan budidaya wortel di dataran rendah tergantung pada pemilihan varietas dan modifikasi fisiologis untuk meningkatkan respon tanaman wortel di dataran rendah. Hasil kajian Fakultas Pertanian Universitas Mataram (KPBI Pengembangan Hortikultura Tropis Berkelanjutan) sebelumnya menunjukkan bahwa beberapa varietas wortel dapat tumbuh dan berumbi di dataran medium dan dataran rendah yaitu varietas Nantes, New Nantes, New Kuroda, Ratu Jabar dan Gundaling (Nikmatullah dkk. 2018a, 2018b, 2019, Zawani dkk., 2018, Amalia dkk., 2019, Lestari, 2019, Hidayat dkk., 2019). Keenam varietas wortel tersebut dapat tumbuh normal dan 
menghasilkan umbi saat dibudidayakan di dataran rendah ( \pm 110 m dpl) (Zawani dkk., 2018; Amalia dkk., 2019, Lestari, 2019, Hidayat dkk., 2019, Nikmatullah dkk., 2019). Hasil umbi tanaman wortel di dataran rendah tersebut cukup tinggi yaitu 50 - 70 g per umbi bila dibudidayakan di dalam polibag secara organik (Zawani dkk., 2018; Amalia dkk., 2019, Nikmatullah dkk., 2019) atau 130 g per umbi bila dibudidayakan secara organik di lapangan (Hidayat dkk., 2019). Potensi hasil wortel di dataran rendah dengan budidaya di lapangan tersebut adalah 17,5 - 22,5 Ton/Ha (Nikmatullah et al., 2021a,b). Meskipun lebih rendah dibandingkan dengan potensi hasil varietas Gundaling sebesar 25 Ton/Ha di dataran tinggi (Anonim, 2018), produksi di dataran rendah tersebut menguntungkan karena kedekatan aksen dengan pasar, tersedianya lahan budidaya yang luas serta harga dan nilai produk lebih tinggi dibandingkan dengan tanaman hortikultura lain yang umumnya dibudidayakan oleh petani di dataran rendah seperti sawi, selada, bawam, kacang tanah dan mentimum. Selain itu, teknologi budidaya tanaman wortel cukup mudah dan tanaman wortel tidak menuntut pemeliharaan yang intensif, sehingga dapat menjadi alternatif komoditas di dataran rendah yang menguntungkan.

Budidaya wortel di dataran belum dilakukan oleh petani. Hal ini antara lain disebabkan oleh kurangnya pengetahuan dan pemahaman petani bahwa wortel dapat dibudidayakan di dataran rendah, dengan hasil yang cukup tinggi, sehingga telah dilakukan PKM untuk mendiseminasikan teknologi budidaya tanaman wortel ramah lingkungan di dataran rendah,

\section{HASIL DAN PEMBAHASAN}

\section{Sosialisasi PKM Kepada Mitra}

Pada kegiatan ini, sosialisasi yang semua direncanakan berupa pertemuan formal berubah menjadi sosialisasi secara terbatas dengan cara tim menjelaskan rencana kegiatan ke UPTD Pertanian Labuapi, kemudian UPTD melakukan koordinasi dan memfasilitasi tim PKM untuk bertemu dengan Ketua dan pengurus gapoktan Bersatu untuk sosialisasi rencana kegiatan. Hal ini dilakukan karena pembatasan sosial dan fisik yang harus dilakukan untuk mencegah penularan virus Covid-19. Dengan keterbatasan tersebut, kegiatan sosialisasi, demplot dan penyuluhan berjalan dengan baik.

\section{Demplot Budidaya Wortel di Dataran Rendah}

Demplot PKM dilaksanakan di lahan milik Ketua Gabungan Kelompok Tani (Gapoktan) Bersatu di Desa Bagik Polak, Kecamatan Labuapi, Kabupaten Lombok Barat yang terletak pada ketinggian tempat $\pm 41 \mathrm{~m}$ dpl. Demplot dilaksanakan sejak bulan Juni (ssetelah panen padi) sampai Oktober 2020, yang terdiri atas 3 blok perlakuan yaitu a blok budidaya secara organik dengan pupuk kandang ayam, b) blok budidaya organik dengan pupuk kandang ayam dan POC Nasa Plus Hormonik, c) blok budidaya non-organik dengan pupuk kandang ayam, 
pupuk NPK dan $\mathrm{KNO}_{3}$. Pelaksanaan demplot ini melibatkan Gapoktan Bersatu dan penyuluh UPTD Pertanian Labuapi. Pelaksanaan demplot ditampilkan pada Gambar 1 - Gambar 3.

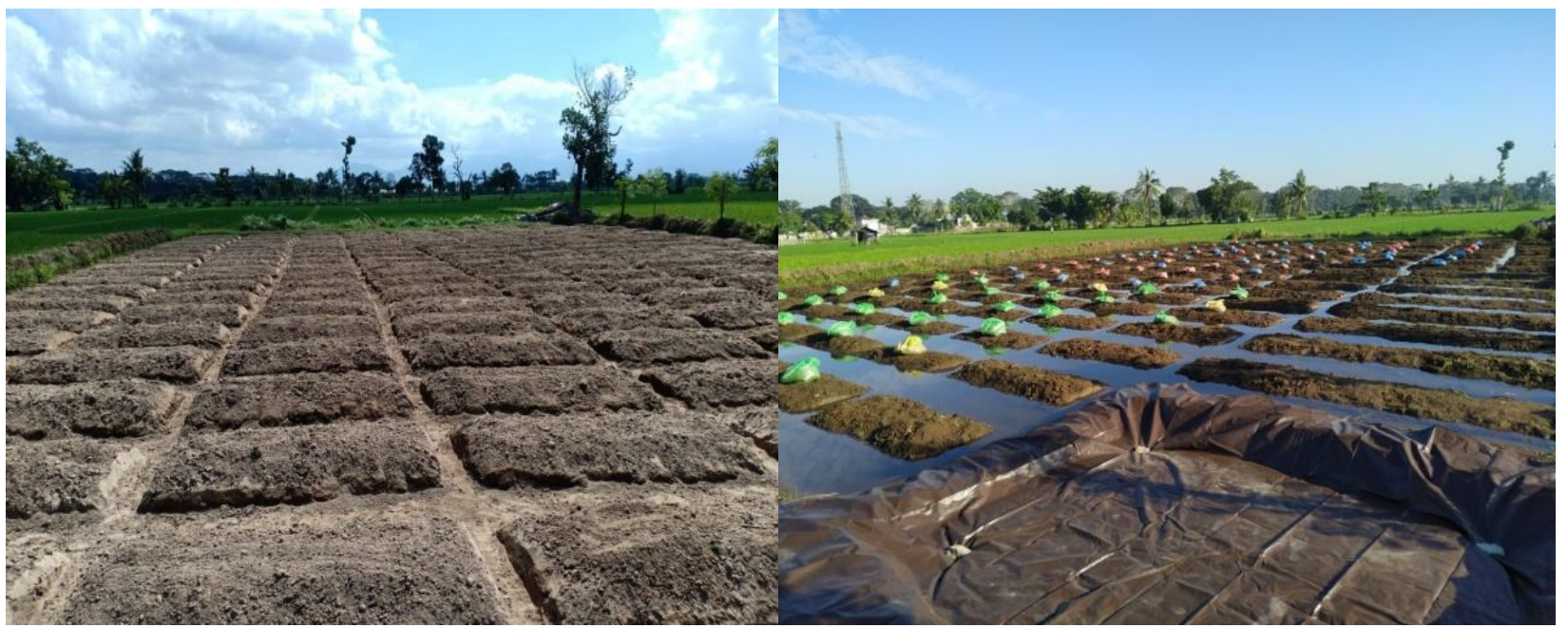

Gambar 1.

Persiapan bedengan demplot budidaya wortel di dataran rendah menunjukkan petak-petak demplot yang sedang diari dengan cara di leb, dan embung buatan untuk antisipasi ketersediaan air selama demplot. Pada gambar juga terlihat posisi lahan demplot yang berdekatan dengan lahan sawah yang sedang ditanami padi.

Pertumbuhan bibit wortel sebelum penjarangan pada demplot cukup bagus ditunjukkan dengan sebagain besar larikan penanaman dipenuhi oleh bibit yang tumbuh dengan subur. Bibit tersebut tumbuh cukup seragam, baik pada perlakuan budidaya ramah lingkungan maupun perlakuan budidaya konvensional. Saat tanaman berumur sampai dengan 4 minggu, tidak terdapat perbedaan pertumbuhan tanaman wortel pada demplot dengan semua sistem budidaya. Tanaman wortel pada demplot PKM ini sudah mulai menghasilkan umbi sejak umur 30 hst, dan pada umur 50 hst umbi makin memanjang dan mulai membesar, dengan panjang $10 \mathrm{~cm}$ dan berat $20-25 \mathrm{~g}$. Hal ini memberikan harapan bahwa demplot budidaya akan memberikan hasil yang cukup baik (Gambar 2).

Tanaman wortel pada demplot PKM ini semuanya dapat menghasilkan umbi dengan mutu yang cukup baik (Gambar 3), dengan berat rata-rata umbi pada demplot dengan pupuk kandang ayam adalah 116,4 g atau setara dengan $2.910 \mathrm{~g} / \mathrm{m}^{2}$, demplot pada pemupukan dengan pupuk kandang ayam dan POC Nasa Plus Hormonik adalah $126,8 \mathrm{~g}$ atau setara dengan $3.170 \mathrm{~g} / \mathrm{m} 2$ dan pada demplot non-organik dengan kombinasi pemupukan menggunakan pupuk kandang ayam, NPK dan KNO3 adalah 135,2 g/tanaman atau setara dengan $3.380 \mathrm{~g} / \mathrm{m}^{2}$ (Tabel 1.). Hasil tersebut menunjukkan potensi hasil budidaya wortel secara ramah lingkungan pada demlot ini cukup tinggi dan mendekati hasil budidaya secara konvensional. 


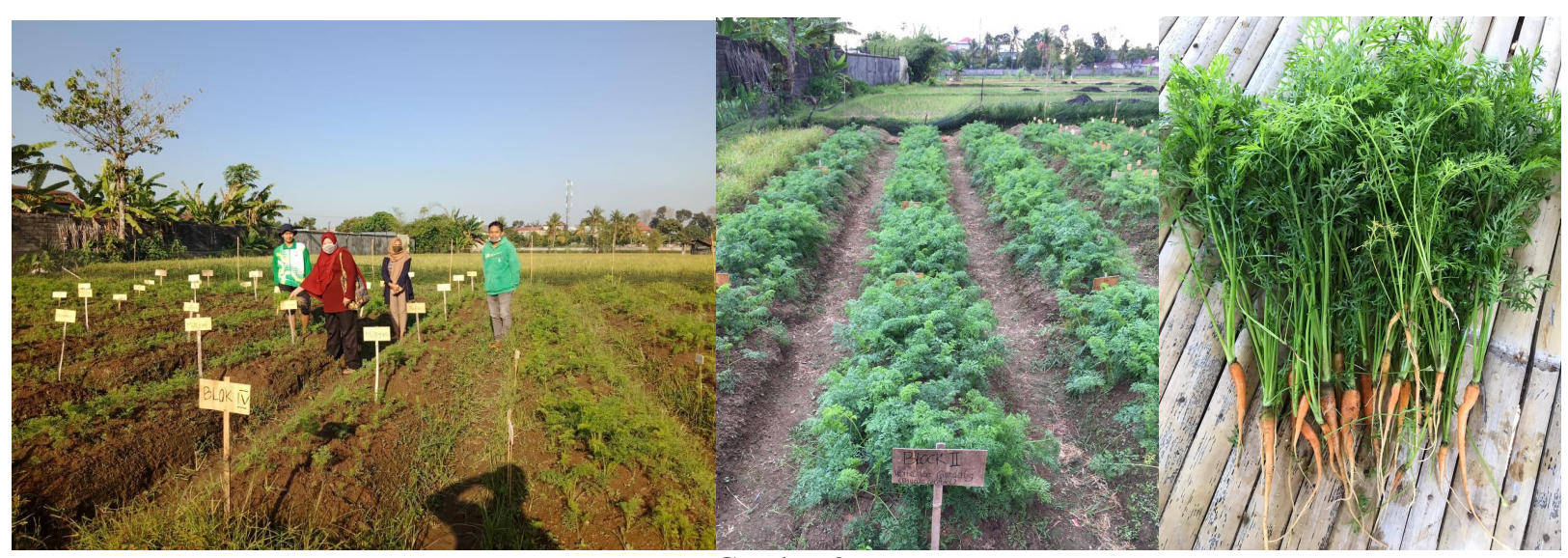

Gambar 2.

Pertumbuhan bibit wortel 4 minggu setelah penaburan benih, sebelum dilakukan penjarangan (gambar kiri) dan 8 minggu setelah penaburan benih (setelah penjarangan, gambar tengah) serta umbi telah terbentuk pada tanaman umur 50 hari setelah tanam (kanan).

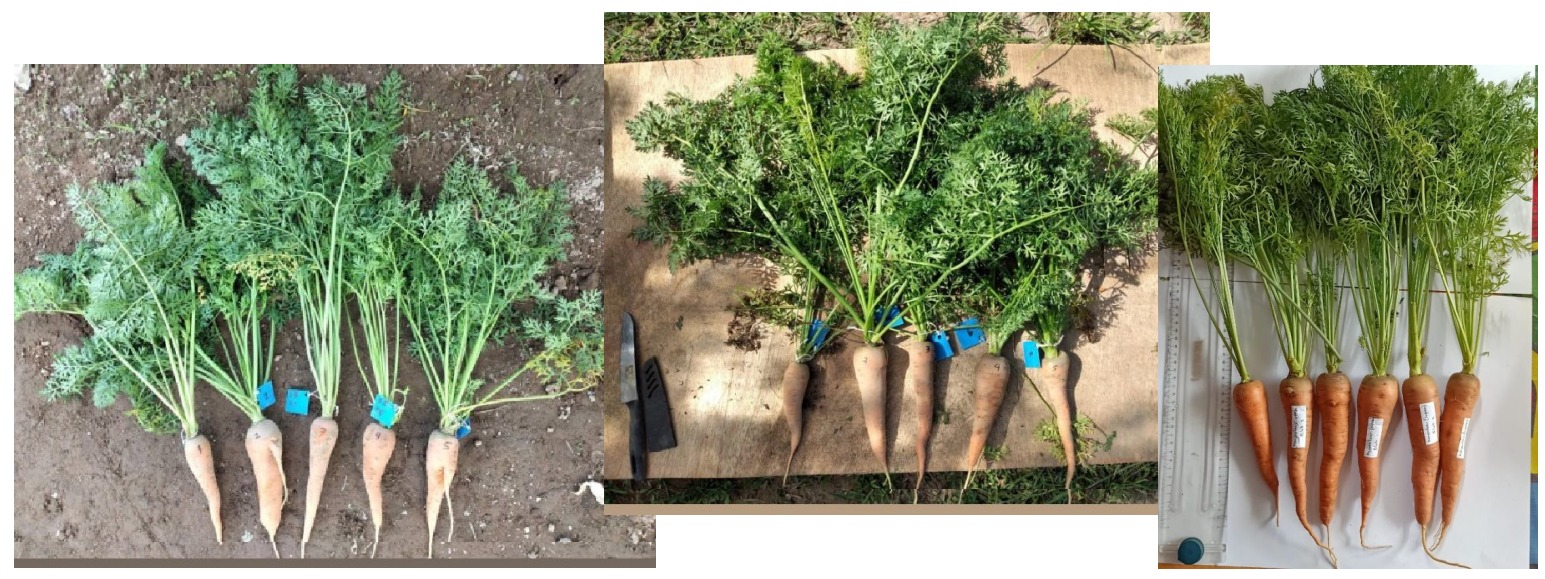

Gambar 3.

Hasil panen wortel pada budidaya menggunakan pupuk kandang ayam saja (kiri), pupuk kandang atam ditambah POC Nasa Plus Hormonik (tengah), pupuk kandang ayam dengan $\mathrm{NPK}_{\text {dan }} \mathrm{KNO}_{3}$ (kanan)

Tabel 1.

Perbandingan hasil demplot pada tanaman yang diperlakukan dengan pupuk kandang ayam, pupuk kandang ayam ditambah POC Nasa plus Hormonik serta kombinasi pupuk kandang ayam dengan NPK dan $\mathrm{KNO}_{3}$ di dataran rendah

\begin{tabular}{llc} 
Perlakuan pemupukan & Berat setiap umbi $(\mathrm{g})$ & Panjang umbi $(\mathrm{cm})$ \\
\hline $\begin{array}{l}\text { Pupuk kandang ayam 20 ton/ha } \\
\begin{array}{l}\text { Pupuk kandang ayam 10 ton/ha + POC NASA } \\
\text { dan Hormonik }\end{array}\end{array}$ & 116,4 & 16,5 \\
$\begin{array}{l}\text { Pupuk kandang ayam 20 ton/ha, NPK 150 } \\
\text { ton/ha, KNO3 100 ton/ha }\end{array}$ & 135,8 & 17,6 \\
\hline
\end{tabular}




\section{Penyuluhan/Ekspose Hasil Demplot}

Ekspose hasil demplot dilakukan bersamaan dengan panen, yaitu saat tanaman berumur 85 hari setelah tanam. Penyuluhan dilakukan di rumah Ketua Gapoktan Bersatu, pada tanggal 6 Oktober 2020. Penyuluhan ini dihadiri oleh 2 orang PPL dari UPTD Pertanian Kecamatan Labuapi, 10 orang anggota Gapoktan, Mahasiswa yang terlibat dalam kegiatan penelitian dan demplot serta tim pelaksana kegiatan PKM. Jumlah peserta yang hadir pada saat penyuluhan dibatasi dikarenakan kegiatan ini harus mematuhi protp Pencegahan Penularan Covid-19 yaitu menjaga jarak, membatasi jumlah peserta, menggunakan masker dan mencuci tangan.

Kegiatan penyuluhan dibuka dan dipandu oleh Ibu $\mathrm{Hj}$. Ida Wahyuni dari UPTD Pertanian Kecamatan Labuapi, dilanjutkan dengan penyampaian materi penyuluhan dari tim dan mahasiswa serta diskusi. Materi penyuluhan disampaikan dengan metode ceramah dengan memberikan penjelasan teknologi dan hasil panen budidaya secara organik dan non-organik. Ketua tim PKM (Ir. Aluh Nikmatullah, M.Agr.Sc.,Ph.D.) menjelaskan tentang tanaman wortel, varietas yang sesuai di dataran rendah serta tahapan-tahapan budidaya tanaman wortel di dataran rendah. Penjelasan dilanjutkan oleh anggota tim-1 (Ir. Karwati Zawani, M.P.) yang menjelaskan tentang pembuatan pupuk organik dan pestisida nabati serta aplikasinya pada tanaman wortel dan tanaman hortikultura lainnya. Ir. Khaerul Muslim, M.Sc.Agr, menjelaskan tentang pemeliharaan tanaman wortel di dataran rendah, OPT yang meyerang tanaman wortel serta pengelolaan OPT. diselingi dengan diskusi, Dr. Ir. Herman Suherti, M.Sc. menjelaskan alasan budidya wortel dilakukan dengan sistem tabela, dan teknik penanaman untuk memperoleh tanaman dengan ajrak yang diinginkan. Ir. Nurrachman, M.Si menjelaskan dan menjawab pertanyaan peserta terkait mutu umbi, penyebab percabangan dan pertumbuhan akar sekunder pada umbi serta teknologi untuk meningkatkan mutu umbi, sedangkan Ir. Rukmini Kusmarwiyah, M.P. menjelaskan teknologi budidaya wortel organik di dalam polybag untuk mendukung program pemanfaatan pekarangan. Foto-foto kegiatan penyuluhan ditampilkan pada Gambar 4 dan Gambar 5.

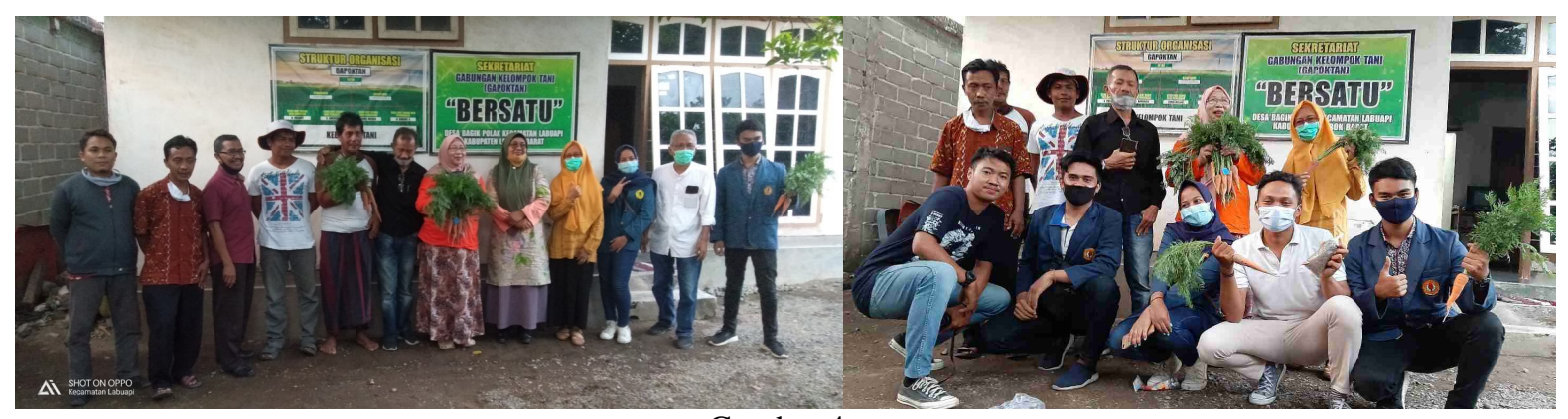

Gambar 4 .

Tim PKM, mahasiswa yang terlibat bersama PPL dan staf UPTD Pertanian kecamatan Labuapi serta Ketua dan Pengurus Gapoktan Bersatu sesaat setelah penyuluhan 


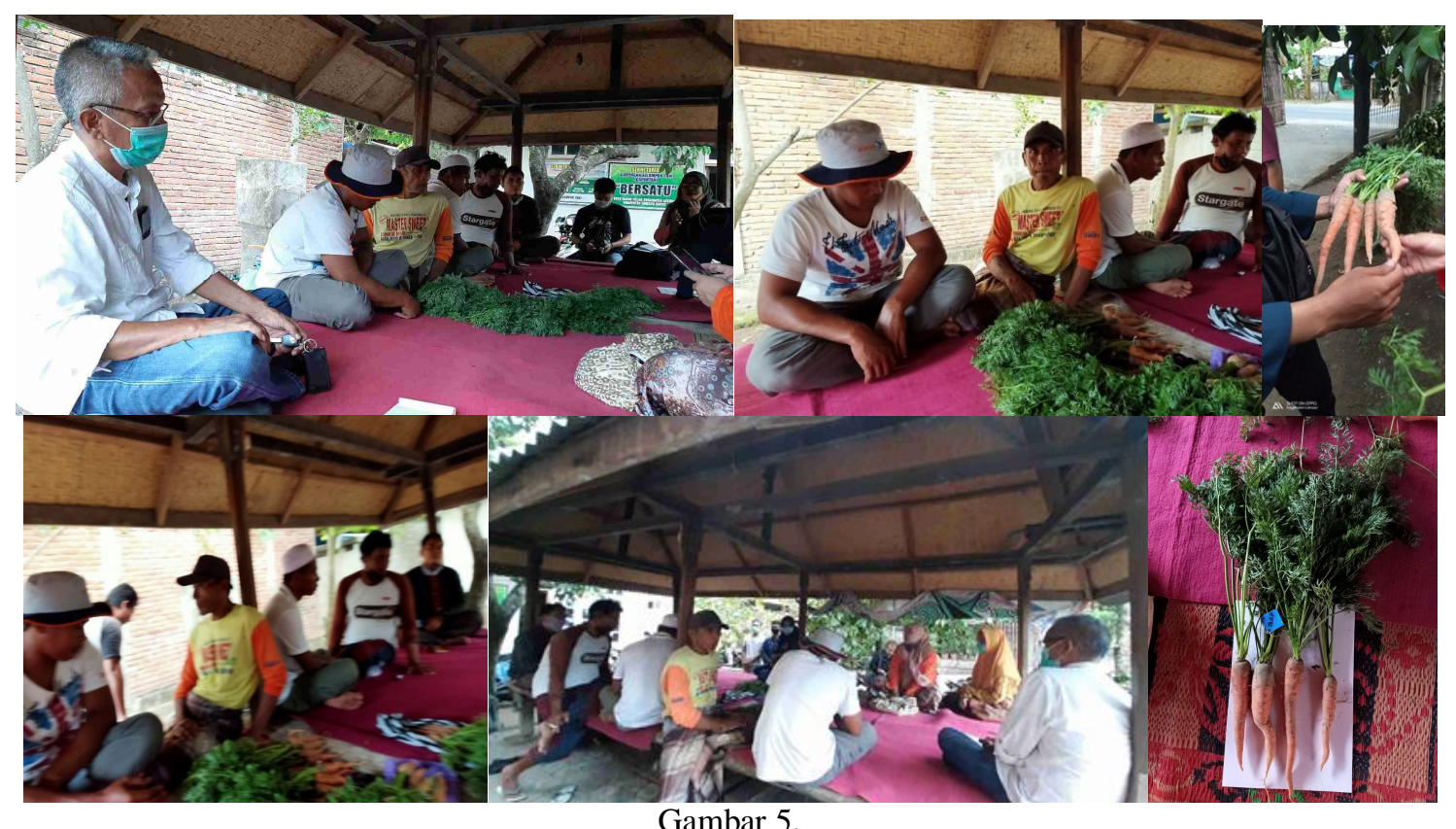

Suasana penyampaian materi dan diskusi membahas hasil demplot budidaya wortel di dataran rendah

Selain tim, mahasiswa yang terlibat pada kegiatan PKM ini yaitu Guntur Gilang Samudra juga memberikan penjelasan kepada peserta (sambil memperlihatkan hasil penelitiannya) bahwa pada budidaya tanaman wortel secara organik di dataran rendah, pupuk yang digunakan adalah pupuk kandang ayam dengan dosis 10 - 20 ton/ha dikombinasikan dengan penyemprotan tanaman dengan pupuk organik cair (POC) Nasa Plus Hormonik untuk meningkatkan hasil tanaman wortel di dataran rendah.

Kegiatan penyuluhan berjalan dengan baik disertai dengan antusias peserta ditunjukkan dengan diskusi yang hangat dan berlangsung dengan baik dan dengan melihat langsung hasil demplot, peserta termotivasi untuk melakukan budidaya tanaman wortel ramah lingkungan secara mandiri. Kelompok mitra akan mencoba penanaman pada lahan sawah dan pekarangan mereka. UPTD Pertanian akan membuat demplot di halaman kantor UPTD Pertanian Desa Labuapi dan akan membuat tanaman wortel sebagai salah satu tanaman dalam program pembinaan pemanfaatan pekarangan di wilayah kerjanya. Selain itu, budidaya tanaman wortel merupakan inspirasi baru bagi petani sayuran dalam melakukan diversifikasi produk sayuran yang memiliki nilai ekonomi yang lebih tinggi.

\section{KESIMPULAN DAN SARAN}

Kegiatan PKM ini berjalan dengan baik, sesuai dengan rencana, yang diawali dengan sosialisasi, diikuti dengan demplot dan ekspose hasil demplot kepada fihak yang relevan. Kerjasama tim dengan UPTD Pertanian Labuapi dan Gapoktan Bersatu Desa Bagik Polak pada kegiatan demplot dan penyuluhan berjalan dengan baik. Hasil demplot menunjukkan budidaya wortel secara ramah lingkungan dan konvensional cukup prospektif untuk 
dikembangkan di Kecamatan Labuapi sebagai upaya diversifikasi produk sayuran dengan nilai ekonomi yang lebih tinggi mauun optimalisasi pekarangan.

Ekspos kegiatan PKM ini terkendala oleh pandemic Covid-19 sehingga dilakukan secara terbatas kepada pengurus Gapoktan Bersatu dan penyuluh UPTD Pertanian Kecmatan Labuapi. Dengan demikian, perlu replikasi di daerah lain dan penyuluhan lebih lanjut untuk mensosialisasikan hasil demplot kepada halayak sasaran yang lebih luas, termasuk kepada ibu-ibu rumah tangga dan PKK guna pengembangan budidaya tanaman wortel di pekarangan untuk mendukung ketahanan pangan keluarga. Hal ini akan menjadi fokus penyuluhan di masa yang akan datang.

\section{Ucapan Terima Kasih}

Penulis mengucapkan terima kasih kepada Fakultas Pertanian Universitas Mataram yang telah atas hibah Pengabdian Kepada Masyarakat dana PNBP Fakultas Pertanian Universitas Mataram Tahun 2020 sehingga kegiatan ini dapat berlangsung.

\section{Daftar Pustaka}

Amalia, R., Zawani, K., dan Nikmatullah, A. 2019. Pengaruh Kosentrasi dan Frekuensi Pemberian Pupuk Hayati Bio-EXTRIM Terhadap Pertumbuhan dan Hasil Tanaman Wortel (Daucus carota L.) dalam Pot di Dataran Rendah. Jurnal Sains Teknologi dan Lingkungan, 5 (2): $112-122$ http://jstl.unram.ac.id/index.php/jstl/issue/view/7

Anonim. 2006. Mengenal Khasiat Wortel. http://lianaindonesia.wordpress.com/2006/12.18. Mengenal-khasiatwortel (diakses pada 2 Maret 2020).

Anonim. 2018. Berita Resmi PVT, Pendaftaran Varietas Lokal No Publikasi 64.BR/PVL/02/2018. Sekretariat Jenderal, Kementerian Pertanian Republik Indonesia, Jakarta.

Berlian, N. dan Rahayu, E. 1995. Wortel dan Lobak. Penebar Swadaya, Jakarta.

BPS. 2020. Produksi Tanaman Sayur-Sayuran di Indonesia. www.bps.go.id. diunduh tanggal 28 Pebruari 2020.

Firmansyah M.A., Liana, T. dan Rahayu., W. 2016. Uji Adaptasi Wortel di Tanah Lempung Liat Berpasir Dataran Rendah Palangka Raya. Jurnal Hortikultura 26 (2): 197 - 206.

Hidayat, R. 2019. Pertumbuhan dan Hasil Tanaman Wortel di Dataran Rendah pada Perlakuan Berbagai Jenis Pupuk Organik dan Jarak Tanam. Skripsi. Fakultas Peranaian, Universitas Mataram, Mataram.

Khomsan, A. 2007. Sehat Dengan Makanan Berkhasiat. Penerbit Buku Kompas. Jakarta.

Lestari, R.D. 2019. Uji Daya Hasil Empat Varietas Wortel (Daucus carota L.) Di Dataran Rendah. Skripsi. Fakultas Pertanian, Universitas Mataram, Mataram. 
Mulyahati, A. 2005. Saluran Tataniaga Wortel di Kawasan Agropolitan Cianjur Skripsi. Fakultas Pertanian, Institut Pertanian Bogor, Bogor.

Nikmatullah, A., Kisman, Zawani, K., dan Santoso, B.B., 2018a. Kaji Terap Pengembangan Wortel di Kabupaten Lombok Utara. Laporan Penelitian Kerjasama Fakultas Pertanian Unram dengan Bappeda Kabupaten Lombok Utara. Fakultas Pertanian, Universitas Mataram, Mataram.

Nikmatullah, A., Zawani, K., dan Muslim, K. 2018b. Pengembangan Teknologi Budidaya Wortel di Dataran Medium. Laporan Penelitian Internal Universitas Mataram, Dana PNBP, Fakultas Pertanian, Universitas Mataram. Fakultas Pertanian Universitas Mataram,Mataram.

Nikmatullah, A., Zawani' K., Muslim, K. and Sarjan, M. 2021. Responses of Four Varieties of Carrot Plant (Daucus carota L.) Grown in Medium Latitude To Different Dosages of Fertilization. IOP Conference Series Earth and Enviromental Science 637012079.

Nikmatullah, A., Khaerunnisa, N., Amalia, R., Zawani, K., and Sarjan, M., 2021. Effecto Biofertilizer on Growth and Yield of Carrot (Daucus carota L.) Plants in Different Latitudes of Lombok Island. IOP Conference Series Materials Science and Engineering 1098(4):042107 . DOI: 10.1088/1757-899X/1098/4/042107

Nunez, J., Hartz, T., Suslow, T., and McGiffen M., 2008. Carrot Production in California. UC Vegetables Research and Information Centre. DOI 10.3733/ucanr.7226.

Que, F , Hou,X.L., Wang, G.L., Xu, Z.S., Tan, G.F. Li ,T. ,Wang,Y.H., Khadr, A., and Xiong, A. 2019. Advances in Research on the Carrot, an Important Root. Horticulture Research 6:69. DOI: 10.1038/s41438- 